\title{
Technology Recognition of Leather Artifacts Belonging to the Achaemenian period, Artifact from the Salt Mine in Zanjan Chehrabad
}

\author{
H.R. IRANI ${ }^{a^{*}}$, M. ZAREI ${ }^{b}$, A. AALI ${ }^{c}$, V. ASKARPUR ${ }^{d}$, A.R. KOUCHAKZAEI ${ }^{e}$ \\ ${ }^{a}$ Department of Conservation and Archaeometry, Faculty of Applied Arts, Tabriz Islamic Art University, \\ IRAN \\ ${ }^{\mathrm{b}}$ Department of Applied Chemistry, Faculty of Chemistry, Tabriz University, IRAN \\ ${ }^{c}$ Head of Archeological Excavation at Historical Salt Mine in Zanjan, Chehrabad, IRAN \\ ${ }^{\mathrm{d}}$ Department of Conservation and Archaeometry, Faculty of Applied Arts, Tabriz Islamic Art University, \\ IRAN \\ ${ }^{\mathrm{e}}$ Department of Conservation-Restoration of Historic-Cultural Properties, Art University of Isfahan, IRAN
}

\begin{abstract}
Organic materials, due to their vulnerable structure, are considered as rare archeological materials. Therefore, the number of research and literature about these materials is limited. In this project, four leather artifacts found in Chehrabad Salt Mine of Zanjan belonging to Achaemenid period have been studied in three sections: first, identifying the type of animal whose skin has been used in producing these artifacts; second, identifying the tanning materials; and third, identifying the materials used in fat liquor processing. For identifying the animal species, cross section of leather samples were studied using optical microscopy method. Results showed that sample no. 1 is of cow skin, sample no. 2 of goat, and sample no. 3 and 4 are of sheep skin. These results can prove the hypotheses related to animal species. For identifying tanning material, presence of plant tanning agents was studied using ferric chemical test. The results revealed the absence of any tanning agents and this disproves the hypotheses related to tanning material. For studying the existence of mineral tanning material, SEMEDS elemental analysis technique was used and the results showed the absence of those mineral material; concluding that no tanning material used in the samples. For identifying the materials used in lubricating process, GC-MS technique was used. Separating organic compounds in samples, this technique also proved the absence of vegetable tanning materials in the process of manufacturing these artifacts and this confirmed the results of ferric chemical test. Comparing the compounds identified by GC with MS library, some fatty acids were recognized. Linoleic acid and stearic acid were identified in sample 1 which shows the presence of sunflower oil. Oleic acid and capric acid (decanoic acid) were identified in sample 2 , but no material could be found with these two fatty acids. Probably two materials have been used in lubricating process of this sample. In sample no. 3, only oleic acid was found. For sample 4, no fatty acid could be found, proving the absence of oil and fat in this artifact. Finally for ensuring the results of GC-MS, FT-IR technique was used. In this regard, two important absorbance bands of fatty acids i.e. $\mathrm{O}-\mathrm{H}$ and $\mathrm{C}=\mathrm{O}$ bonds were considered. All samples, except sample no. 4, showed absorption in mentioned areas. Thus FT-IR confirmed the result of GCMS analysis. These results support the hypotheses given about the materials used in lubricating process of the samples.
\end{abstract}

Keywords: Salt men, Leather Technology, Chehrabad, FT-IR, SEM-EDS, GC-MS.

* - Corresponding author: h.irani1990@gmail.com 


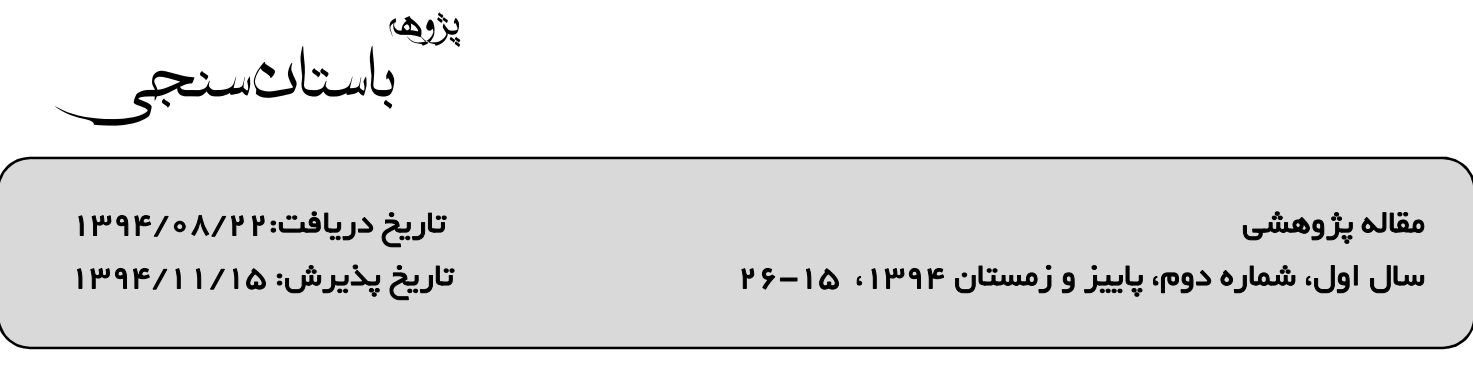

\title{
بازشناخت فناورى مصنوعات جرمى متعلق به دوره هخامنشى، مكشوفه از

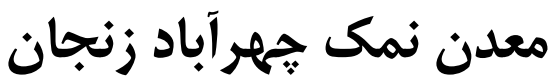

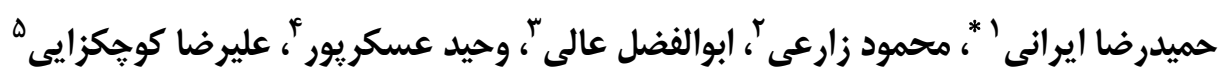

\author{
I. كارشناس ارشد باستانسنجى، دانشكاه هنر اسلامى تبريز، ايران.

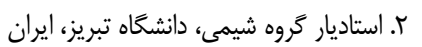

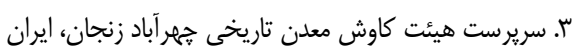

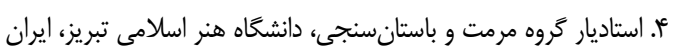

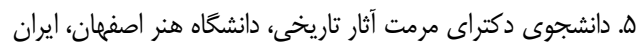

\section{جكيده}

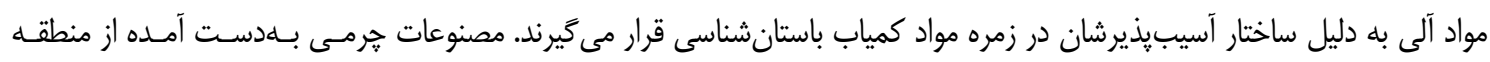

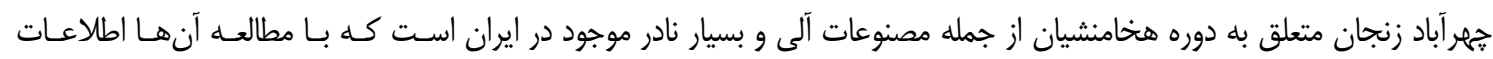

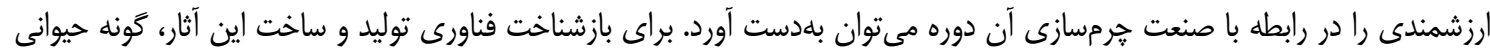

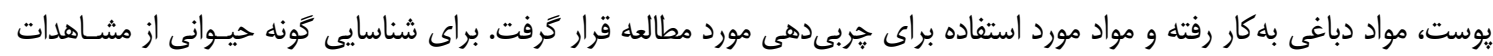

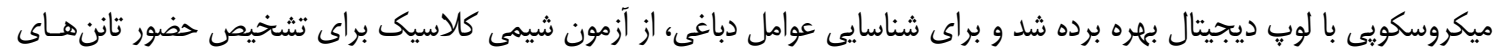

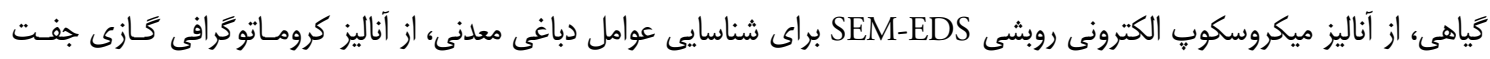

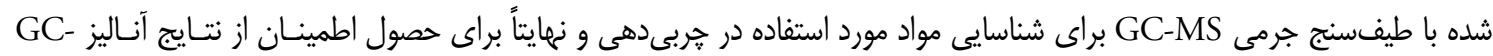

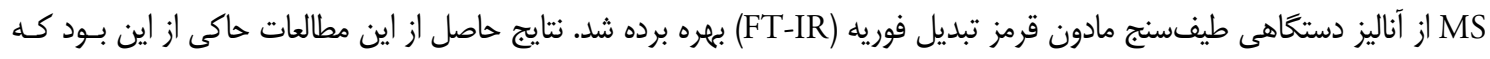

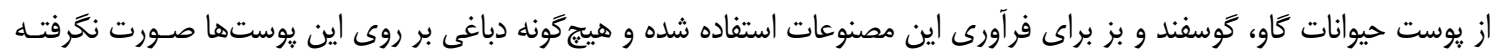

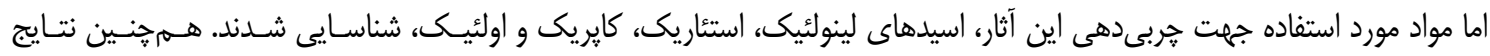

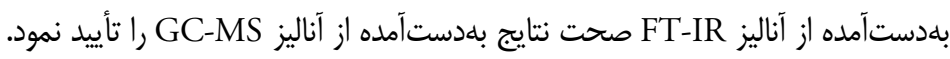

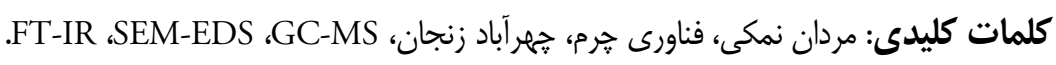

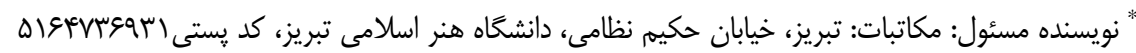

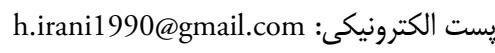

C) حق نشر متعلق به نويسنده(كان) است و نويسنده تحت مجوز Creative Commons Attribution License به مجله اجازه مىدهد مقاله خاب شده را با ديخران به اشتراك بكذارد منوط بر اينكه حقوق مؤلف اثر حفظ و و به انته انتشار اوليه مقاله در اين مجله اشاره شود. 
اغلب يزوهشهاى انجام شده در زمينه فناورى مصنوعات يوسـتى در ايـران رويكـردى مرمتسى داشـته و تحقيقـات محدودى در حيطه تحليل فناورى مصنوعات جرمى انجام شده است همجينين تـاكنون در زمينـه هـرمســازى دوران هخامنشى هيج يزوهشى صورت نخرفتـه استـ عليرضـا كوجيزايى و همكارانش مقالهاى تحت عنوان فنشناسى

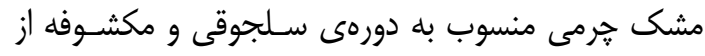
قلعه كوه قائن بر اساس مطالعات آزمايشگاهى ارائه دادهاند كه در آن به بررسى فنشناسى نمونسه مـورد مطالعـه بـا

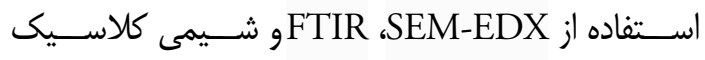
يرداخته شد كه نتايج نشاندهنده استفاده از كلانيك (Spot tests)

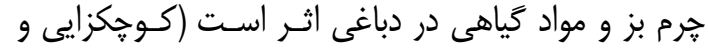

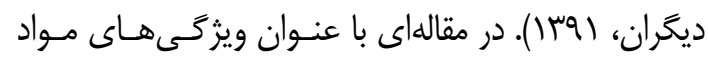

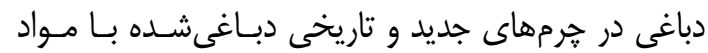

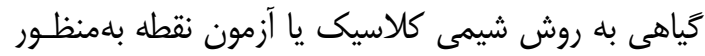

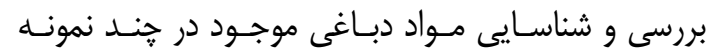
تاريخى از آزمون فريك براى شناسايى تاننهاى هيدروليز شونده، آزمون وانيلين (

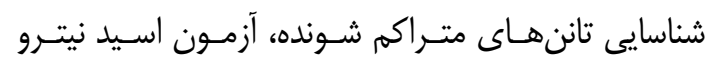
براى شناسايى الاكى تاننها و آزمون رودانسين

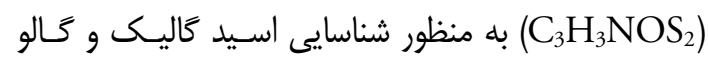
تاننها استفاده شده است (Falcao \& Eduarda, 2011). در مقالهاى با عنوان تكنيكهــاى آنـاليزى اسـتفاده شـده

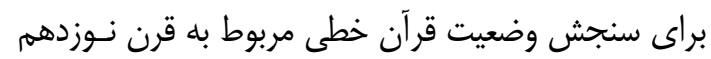
ميلادى بلمنظور بررسى و فنشناسى مواد مـورد اسـتفاده در ساخت كاغذ و קرم موجود در اثر براى شناسايى گونسه

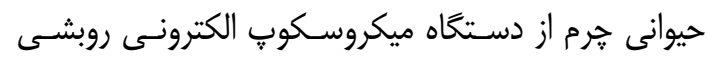

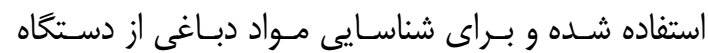

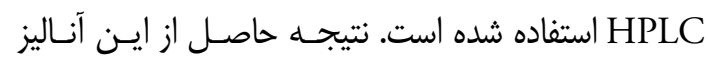

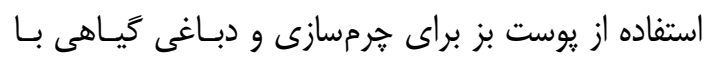
استفاده از درخت اقاقيا عربى كزارش شده اسـت (-Abdel

.(Maksoud, 2011

\section{ץ-1 -معرفى معدن جهر آباد محوطه باز شناخت موميايى هاى نمكى ايران} معدن نمك جهر آباد با ارتفاع •هـا متران متر از سـطح دريـا در
مواد آلى در دستههاى متفاوتى از مواد فرهنكى بلهصـورت

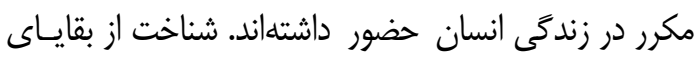

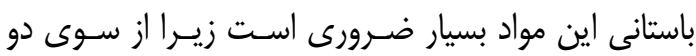

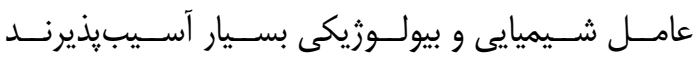

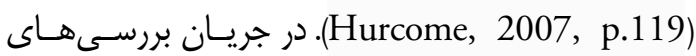
باستان شناسى معادن نمـك در منطقـهـ هِر آبـاد زنجــان،

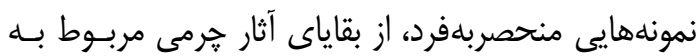
مردان نمكى اين منطقه كشف شد. شرايط محيط تـدفين در اين محوطه به سبب وجود حجم زيـاد نمـك، مـانع از

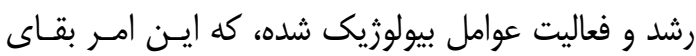
اين آثار را موجب كَديده است. اين شرايط خاص محيط ئريط

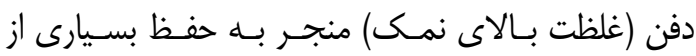

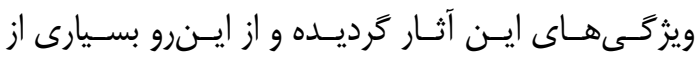
خصوصيات اين نمونهها قابل درك و شناسايى هستند. بـر مبناى ساليابى و مطالعات صورت كَرفته آثار مذكور متعلق

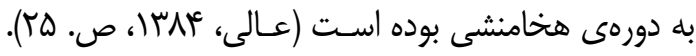
از اينرو اطلاعات و ارزشهاى نهفتـه در ايـن آثار و نيـز

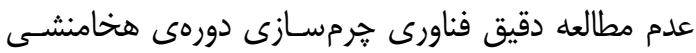

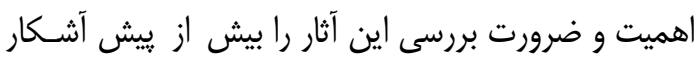
مى كند. لذا در اين يزوهش بلممنظور بازشناخت تكنولـوزى اينى

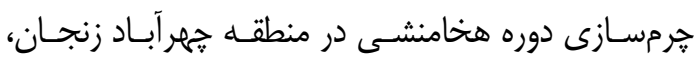

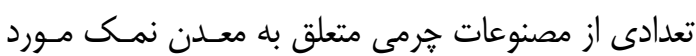
بررسى قرار مى گيرد. بررسى آزمايشكاهى اين آثار بر پايـهـ

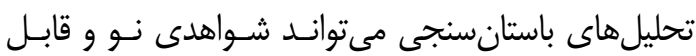

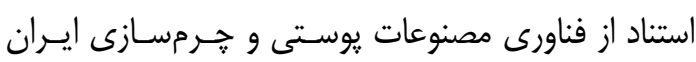
باستان ارائه نمايند. براى رسيدن به نتــايج قابـل اسـتناد از

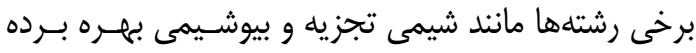

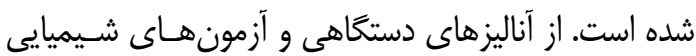
و شيمى تجزيه براى شناسايى مواد بهكار رفته در سـاخت

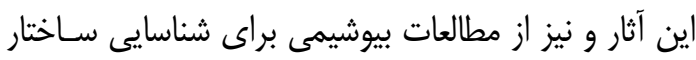

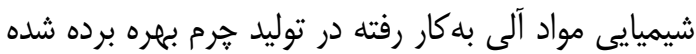

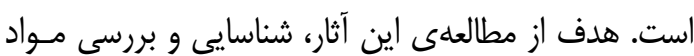

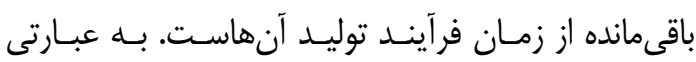

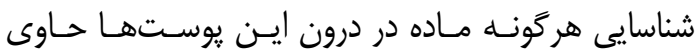

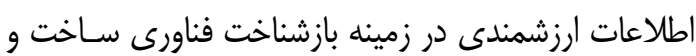

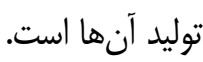

| | سال اول، شماره دوم، ياييز و زمستان ع وسر| 


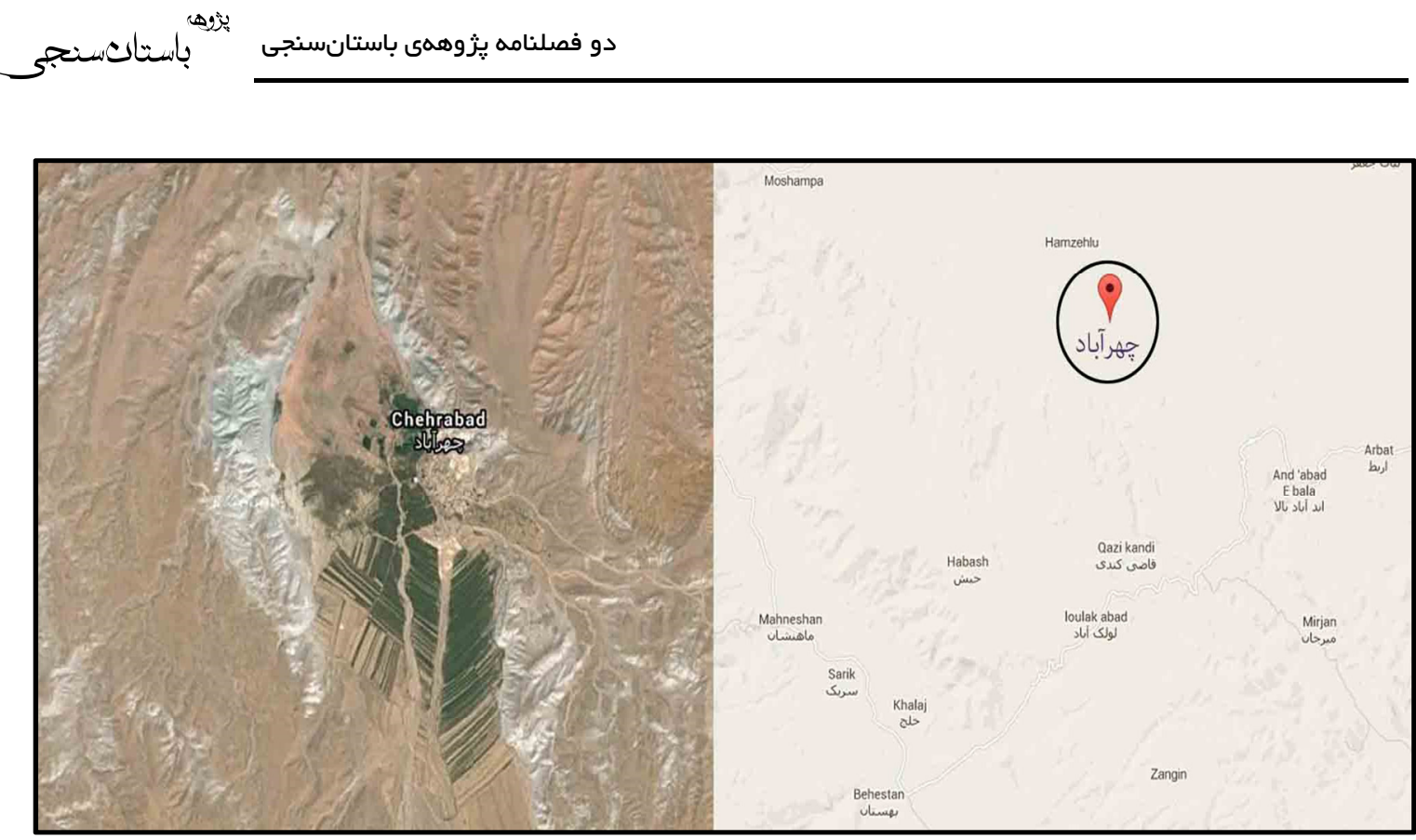

شكل ا: تصوير هوايى موقعيت جغرافيايى منطقه جهر آباد زنجان (مأخذ نقشه هوايى: Google Earth, 2015 )

بيشينه اطلاعات موجود از نهشتههاى آشفته شـده معـدن

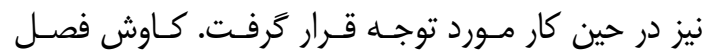

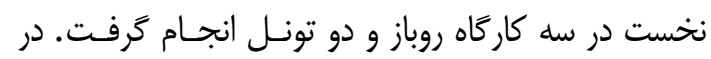
فصل دوم علاوه بر ادامه كاوش در كاركاههاى يُش

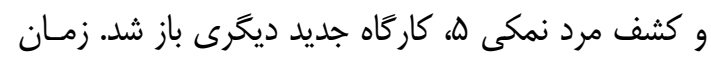

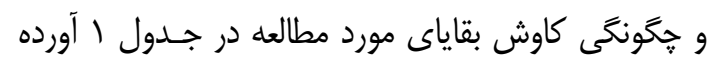

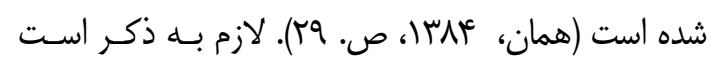

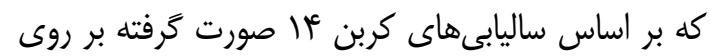

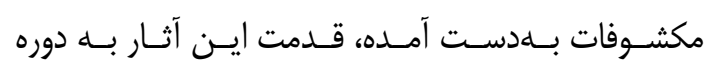
هخامنشى برمى

\section{س - مواد و روش ها} r-r- نمونهبردارى و آمادهسازى

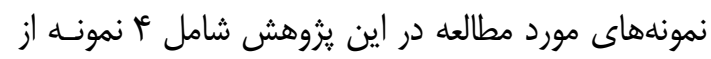
مكشوفات جرمى معدن نمك جهر آباد است كه يكى نمونه كيسه منسوب به مرد نمكى شماره ه، يك نمونسه كفـش
كيلومترى غرب شهر زنجان و يك كيلومترى جنـوب VD

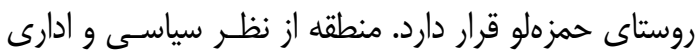
مربوط به دهستان غنىبيشلو از توابـع شهرسـتان زنجـــان است (عالى، عربا، ص. عץ) (شكل ()).

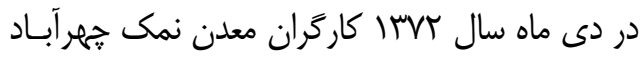
زنجان در حين كار با بولدوزر و اسـتخراج نمـك، نـيمتتـه داله انسانى را كه ريش و موى بلند داشــ؛ يافتنـد. در همـان

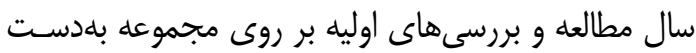

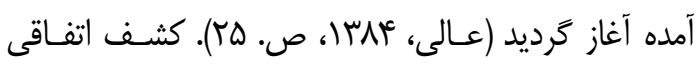

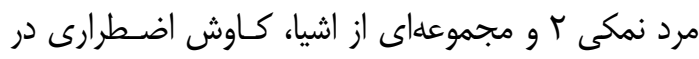

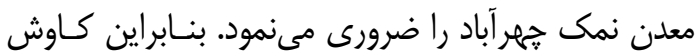

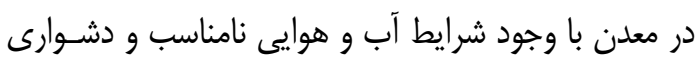

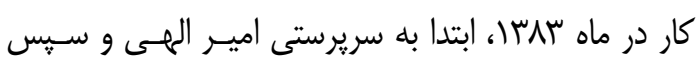

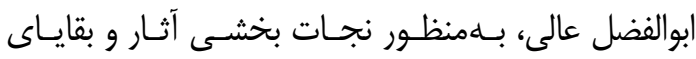

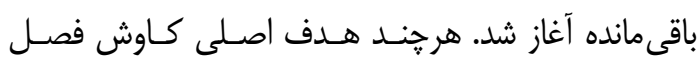

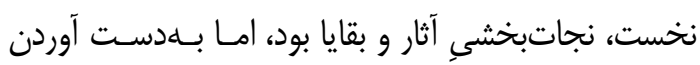

جدول (: زمان و نحوه كشف نمونههاى مورد مطالعه

\begin{tabular}{|c|c|c|c|}
\hline & بقاياى بهدست آمده & نحوه كثف & سال \\
\hline & مرد نمكى شماره ا & بلهصورت اتفاقى & IrVT \\
\hline \multirow{3}{*}{ كمربند، كيف، كفش، كيسه و نوار جرمى و... } & مرد نمكى شماره سا، & بلهورت اتفاقى & זגוזו \\
\hline & كيسه جرمى & فصل نخست & זגוז \\
\hline & مرد نمكى شماره هـ & فصل دوم & Ir人e \\
\hline
\end{tabular}

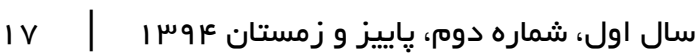


جدول ז: ساليابى نمونهاى كشف شده از معدن نمك جهر آباد (pollard \& others, 2008, p. 137)

\begin{tabular}{|c|c|c|c|c|c|c|}
\hline Mummy \# & $\begin{array}{l}\text { Sample } \\
\text { description }\end{array}$ & C14 age & Error & $\begin{array}{l}\text { delta } \\
13 \mathrm{C}\end{array}$ & $\begin{array}{l}\text { delta } \\
15 \mathrm{~N}\end{array}$ & $\begin{array}{c}\text { Calibrated date BC/AD } \\
(95.4 \%)\end{array}$ \\
\hline SM3 & leather & 2376 & 31 & -22.6 & 8.5 & $540 \mathrm{BC}(92.8 \%) 380 \mathrm{BC}$ \\
\hline SM5 & $\begin{array}{l}\text { Human } \\
\text { skin }\end{array}$ & 2286 & 28 & -20.2 & 15.1 & $300 \mathrm{BC}(30.1 \%) 230 \mathrm{BC}$ \\
\hline
\end{tabular}

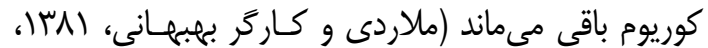

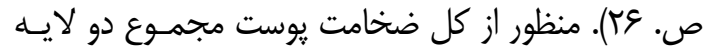
كرين و كوريوم است. بـراى آمـادهـازى نمونسه، سـطح

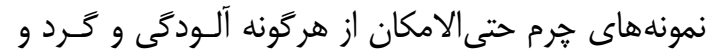
غبار تميز شدند تا حفرات ايجاد شده توسط مـوى حيـان التهان

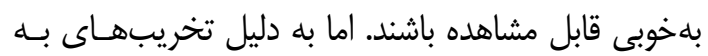

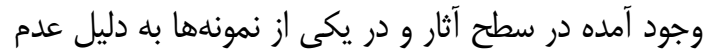
موزدايى و قابل تشخيص نبودن حفرات موجـود در سـطح

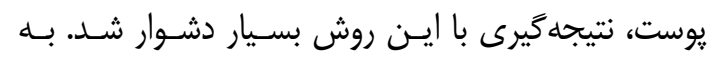

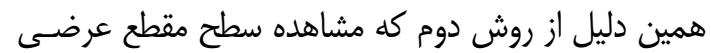
نمونه بود، استفاده شد.

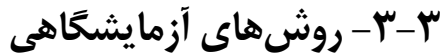

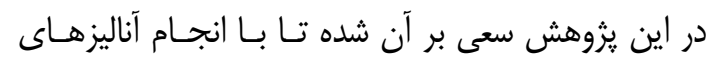

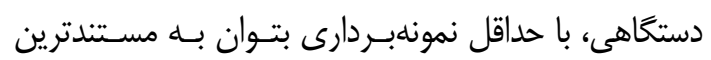

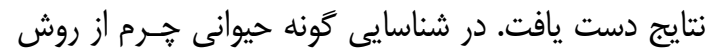
مشاهده ميكروسكويى استفاده شد و براى رسيدن به نتايج

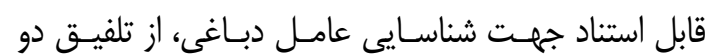

منسوب به مرد نمكى شـماره لّ و دو نمونـه منسـوب بـهـ

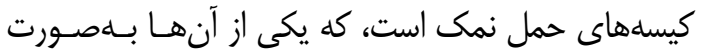

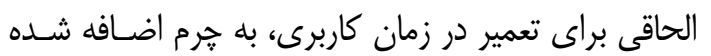
است (شكل r).

براى نمونهبردارى لازم بود ابتدا مقدار حرم مورد نيـاز

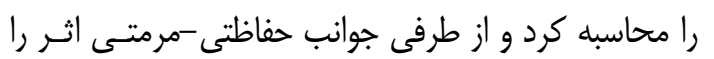

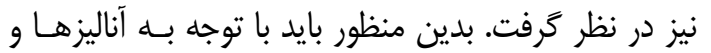

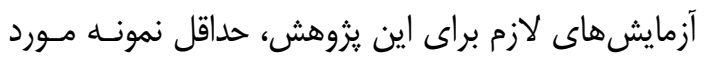

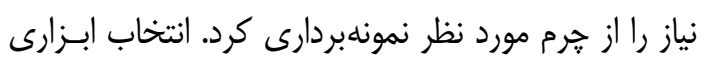
بُرنده و ظريف همجِون تيغ بيستورى در اين مرحله از اين

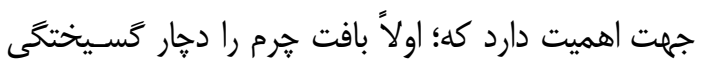

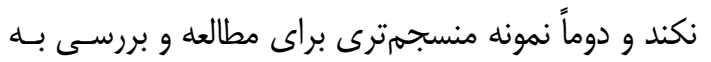
دست دهد. هركاه برش عرضى بسيار نازى از يك يوست در زير

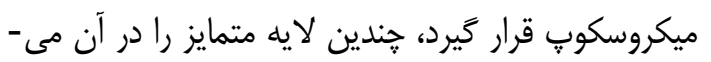
توان به آسانى تشخيص داد. اين لايهها عبارت از إيـدرم،

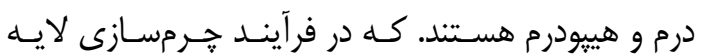

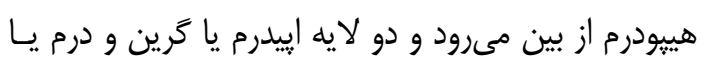

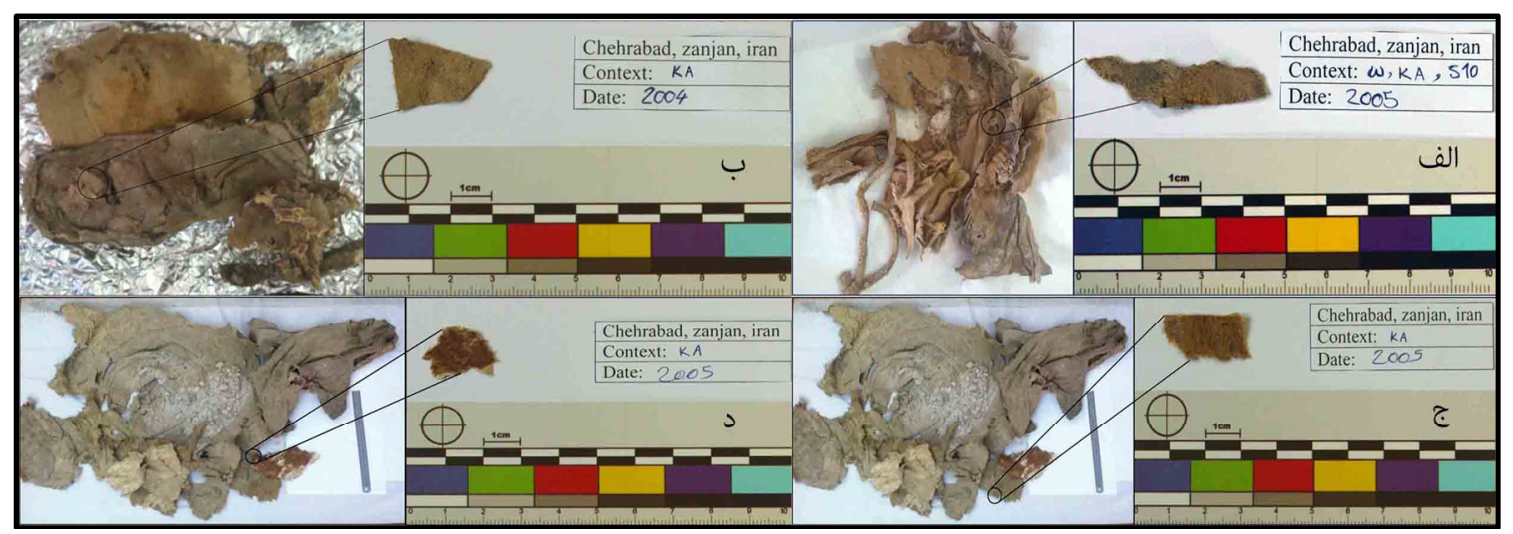

شكل r: نمونههاى مورد مطالعه - الف: نمونه كيسه منسوب به مرد نمكى ه؛ ب: نمونه كفش متعلق به مرد نمكى ب؟ ج: نمونه اصلى كيسه حمل

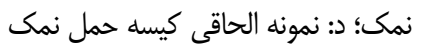




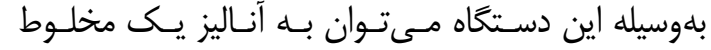

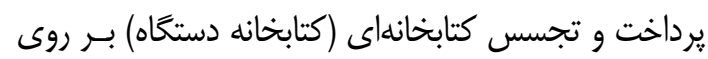

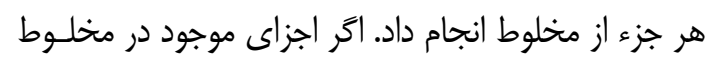

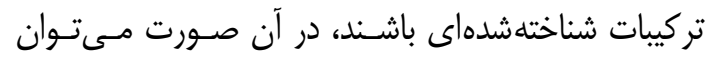

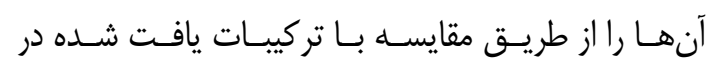

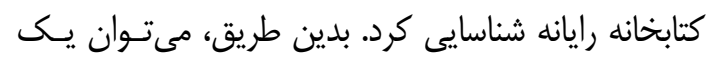

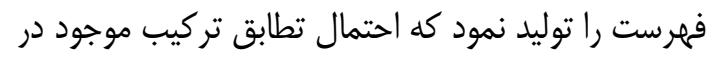

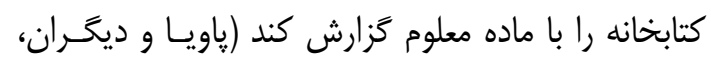

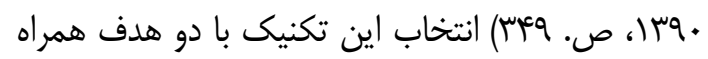

اطمينان از نتـايج آزمـونِ شـيميايى بـراى شناسـيى عوامل دباغى گياهى

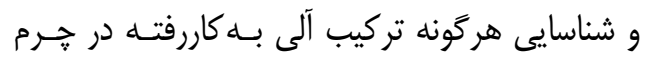

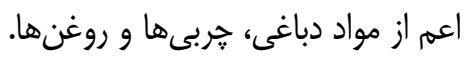
بـاينوجـود آنـاليز GC-MS نقـش مهمسى در شناسـايى

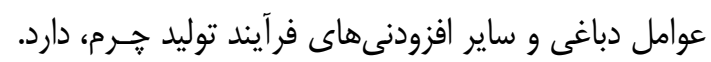

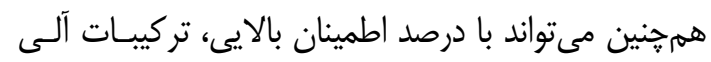

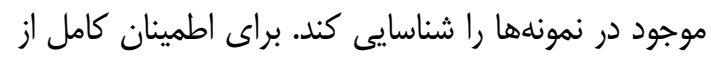

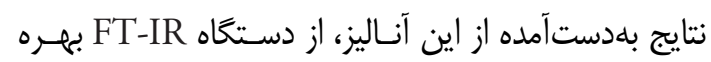
برده شد.

\section{f - - نتايج و بحث}

مختصراً بايد كفت در يوست بز لايه كرين يك سوم كـل ضخامت را شامل مىشـود و اليـاف لايـــ كوريـوم نسـبتاً

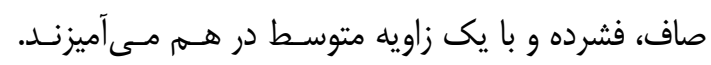
الياف لايه كوريوم در هم تنيدگى ملايمى در اليـاف لايسه

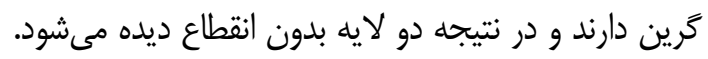

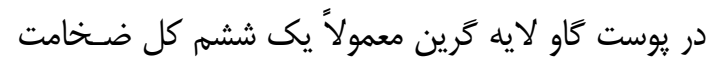

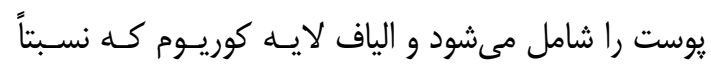

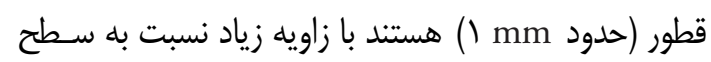

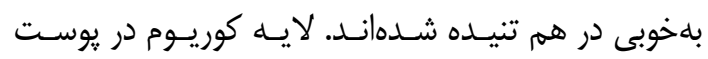

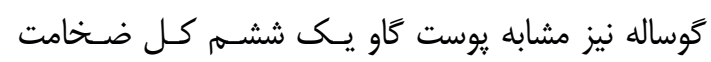

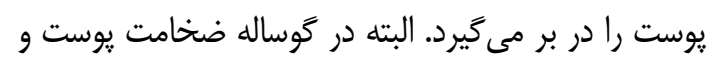

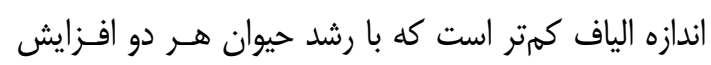

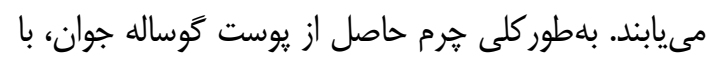

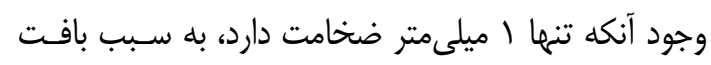

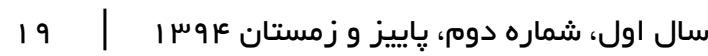

روش آزمايشكاهى و دستخاهى استفاده شد. بـدين منظـور روش آزمايش شيمى كلاسيى (آزمون فريك (كلريد آهن آهن و أFeCL و از آناليز SEM-EDX براى وجود عوامل معدنى و آنـاليز شTIR و GC-MS

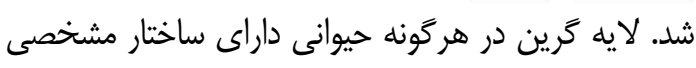

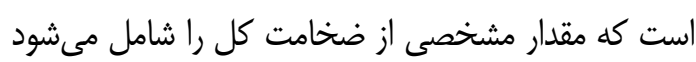
(Haines, 2006, p.12) تكنيك مشاهده ميكروسكويى سطح لايه كرين يوسـت و سطح مقطع يوست صورت گرفت.

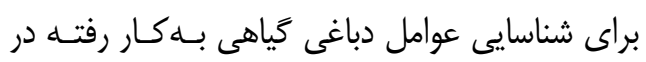

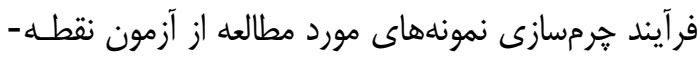

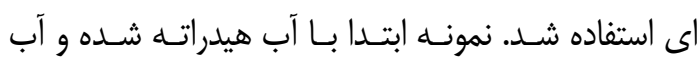

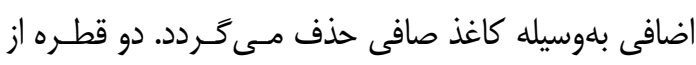

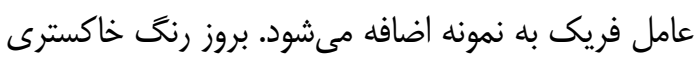

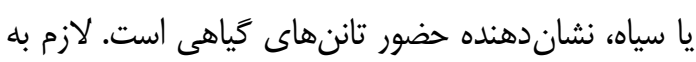

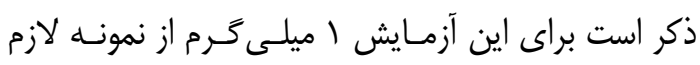

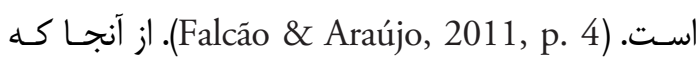
تاننهاى كَياهى، معمولاً به دو دسـته تـاننهـاى متــراكم

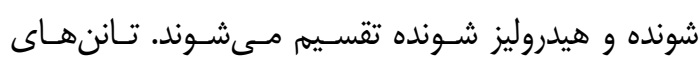

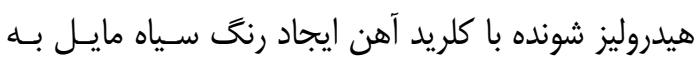

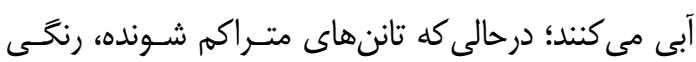
مايل به سبز ايجاد خواهند نمود. در ادامه براى حصول اطمينان از وجود مـواد دبـاغى إنى

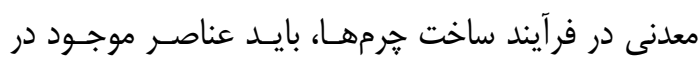
קرم بررسى شوند. بلعنوان مثال: در دباغى معدنى بـ بـا زاج

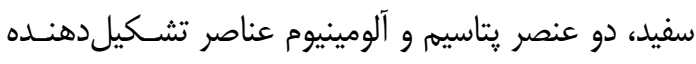

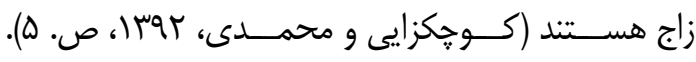

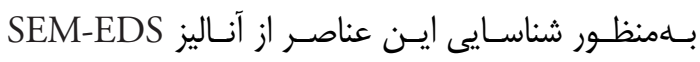

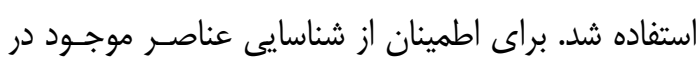

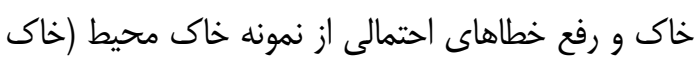

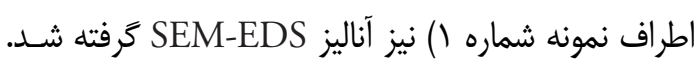

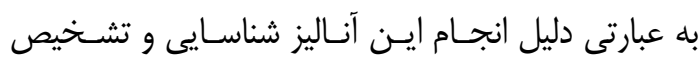

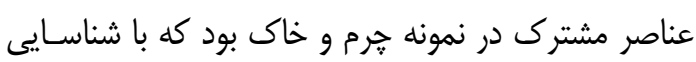
آنها، خطاهاى احتمالى، محاسبه تردند.

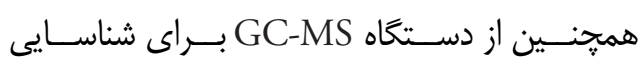

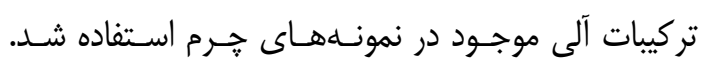




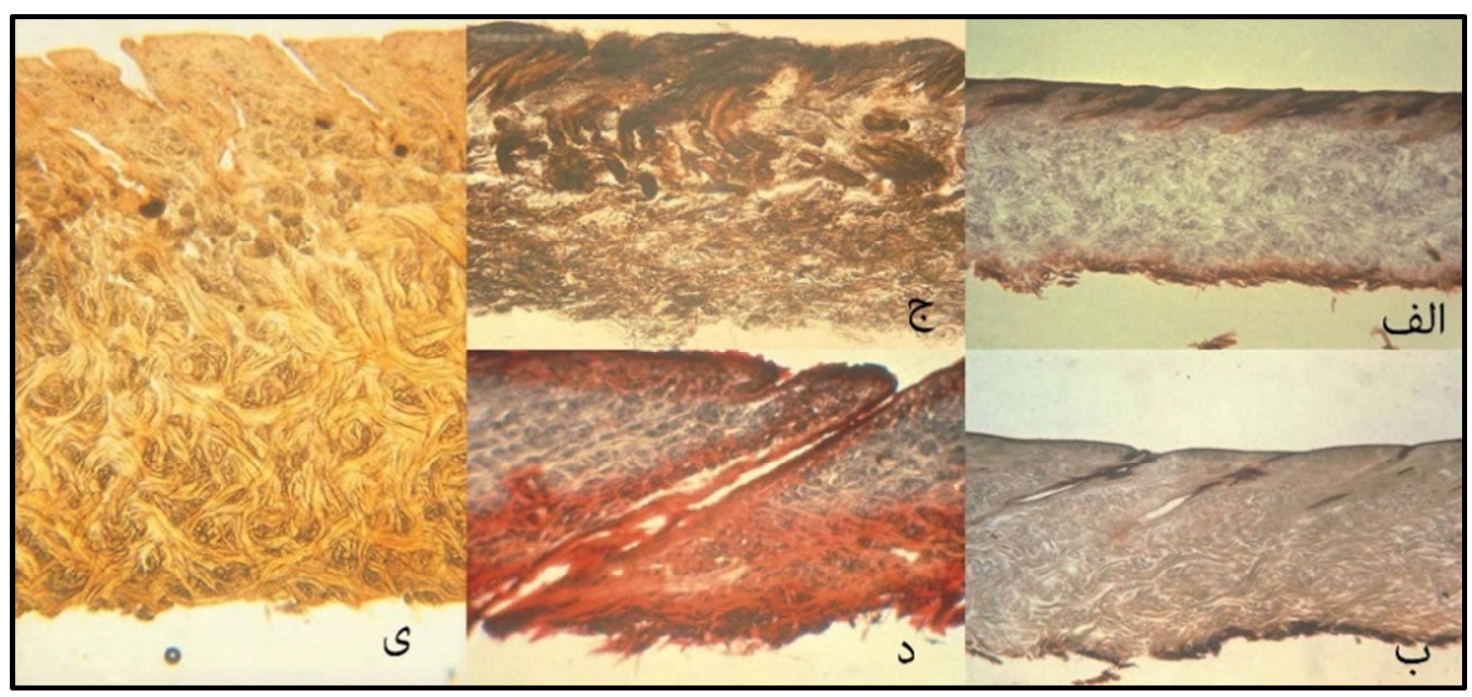

شكل "ّ: تصاوير مقطع عرضى جرم - الف: يوست گوساله؛ ب: يوست بز؛ ج: يوست گوسفند؛ د: يوست خوك؛ ى: يوست كاو

مطالعه كه نتايج آن در جدول ب آورده شــده اسـت، عـدم حضور عوامل دباغى گياهى را نشان داد.

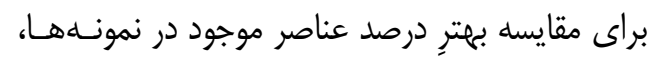

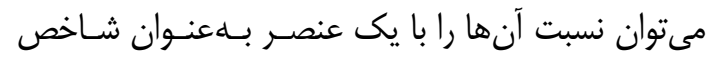

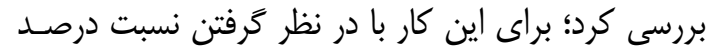

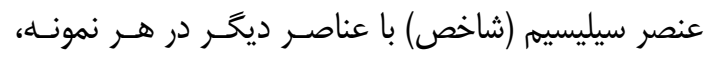

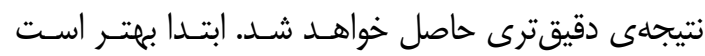
براى تشخيص مواد ناخالص مثل مـواد موجـود در خـاك

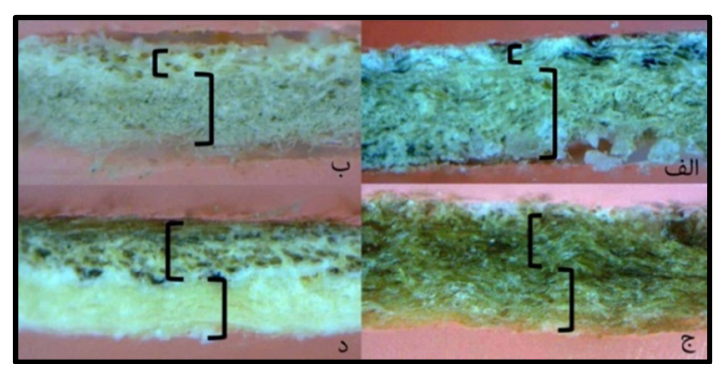

شكل ثا: تصاوير ميكروسكويى از سطح مقطع نمونهها كه لايه كَرين در آنها مشخص شده است - الف: نمونه شماره يك؛ ب: نمونه شماره r؟ ج: نمونه شماره س؟ د: نمونه شماره أ

جدول ": نتايج حاصل از آزمون فريى

\begin{tabular}{|c|c|c|}
\hline آزمون فريك & نتيجه & نمونه \\
\hline$\times$ & عدم حضور تانن گَياهى & 1 \\
\hline$x$ & عدم حضور تانن گَياهى & r \\
\hline$x$ & عدم حضور تانن گَياهى & r \\
\hline$x$ & عدم حضور تانن كَياهى & f \\
\hline
\end{tabular}

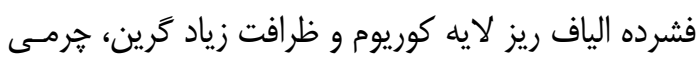
با استحكام بالا است. در يوست كوسـفند، اليـاف كوريـوم

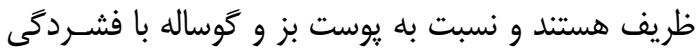

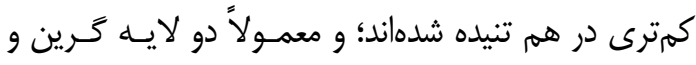

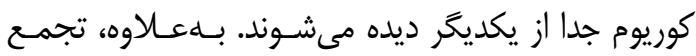
سلولهاى خرب در نقطه تماس بين اين دو لايـه مـانع از

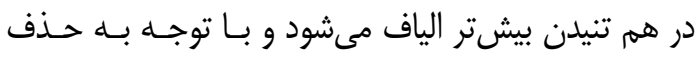

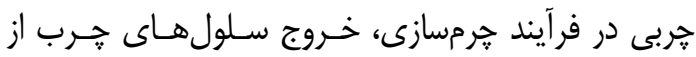
ساختار موجب تشديد جدايش دو لايه از يكديخر مىشـود (شكل ऍ). (haines, 2006, p. 12)

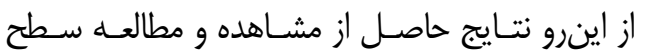

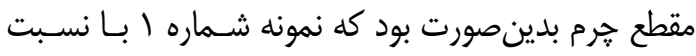

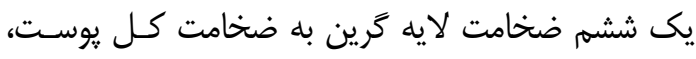
يوست كاوى تشخيص داده شد. نمونه شماره r بــه دليـل

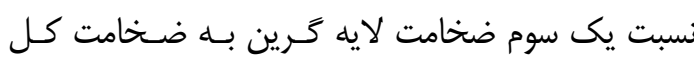

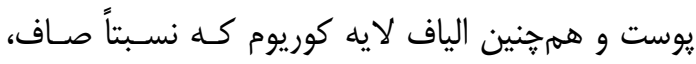

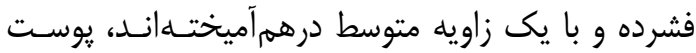

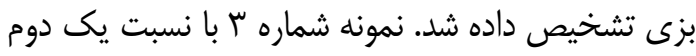

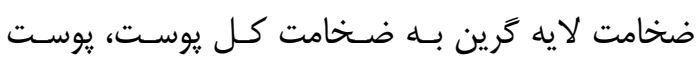

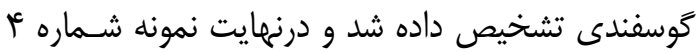

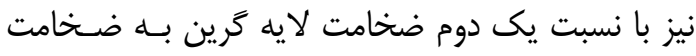

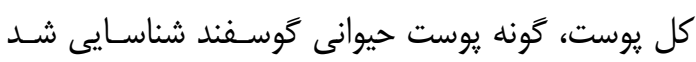
(شكل ع). (ش). (ش). نتايج حاصل از آزمون فريك بر روى نمونههاى مورد

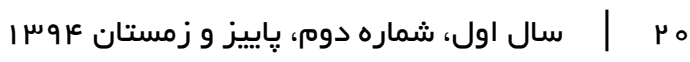


كلسـيم در نمونـه، احتمــال اسـتفاده از كربنـات كلسـيم

بهعنوان مو زدا در فرآيند دباغى را كاهش مىدهد.

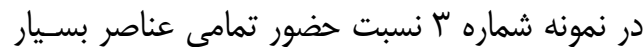

هايين است. حضور MV درصـدى عنصـر سيليسـيم و بـالا بودن مقدار اين عنصر نسبت به ساير عناصر، سندى مبنى بر عدم استفاده از عوامل دباغى معدنى در اين نمونه است. همجنين نسبت حضور عنصر كلسيه (ا به سر/عا ) در اين نمونه نسبت به نمونه خاك بسيار كم است و ايـن گويـاى عدم استفاده از كربنات كلسيه در مرحله موزدايى اثر است.

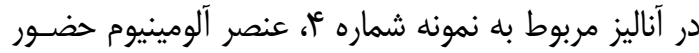
ندارد اما دو عنصر يتاسيهم و سولفور درصد قابل تـوجهى رال به خود اختصاص دادهاند. به نظر مىرسد اين مقــدار قابـل توجه از سولفور موجود در اين نمونه به بييوندهاى سـولفور موجود در موى حيوان مربوط مسىشـود. از طرفـى وجـود

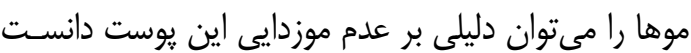
يس استفاده از كربنات كلسيهم جهت عمل مـوزدايى بعيـد به نظر مىرسد؛ هـمهزتـين نسـبت يـايين درصـد عنصـر

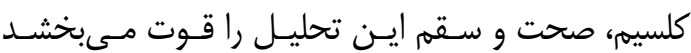

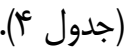

در بخـش بعـدى مطالعـات، در تركيبـات جــدا شــه بلهوسـيله دسـتخاه GC-MS، تركيبـاتى مبنـى بــر وجـود عوامل دباغى يديدار نشد. اين امر بدان معناست كه نتيجه حاصل از آزمون نقطهاى فريك، بدون خطـا بــوده اسـت.

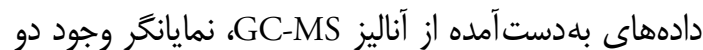

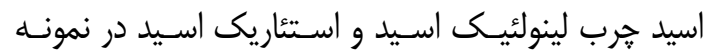

محيطى دادههاى مربوط به آناليز خاك مورد مطالعه قـرار

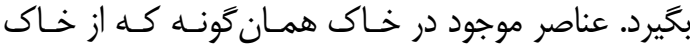
موجود در يك معدن نمك انتظار مىرود بـا درصـد قابـل مونل توجهى از سديم و كلر تشكيل شده اسـت. ديخـر عناصـر مانند سيليسيه، آلومينيوم، كلسيه، منيزيه، يتاسيهم و فســر نيز بلهورت معمول در خاك وجود دارند. حضـور عناصـر تشكيل دهنده زاج سفيد (آلومينيوم و يتاسيم و سولفور) در نمونه شماره ا مشاهده مىشود (جدول ب)؛ اما نمسىتـوان

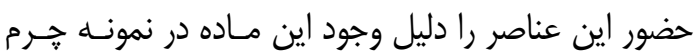
دانست زيرا اختلاف نسبت عناصـر آلومينيـوم و يتاسـيم و سولفور به سيليسيم در نمونه خاك (به ترتيـب: ا بـه ه/هاه

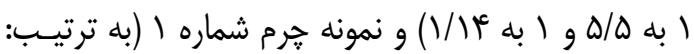

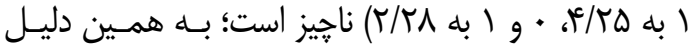

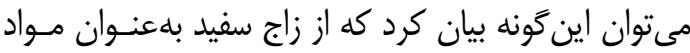

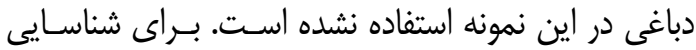
مواد مورد استفاده جهت موزدايى با آهك (كربنات كلسيم)

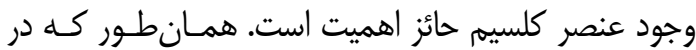
جدول ع مشاهده مىشود حضور اين عنصر در اين نمونسه

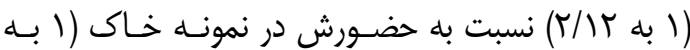
(I/V.

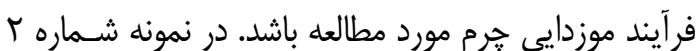

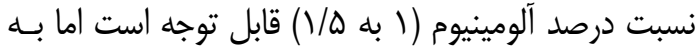
دليل عدم حضور عنصــر يتاسـيم و نسـبت يـايين عنصـر

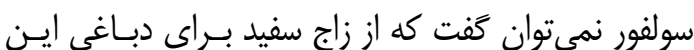
نوع يوست، استفاده شده است. همجنين حضور كـمرنــ

جدول †': درصد عناصر موجود در نمونه

\begin{tabular}{|c|c|c|c|c|c|c|c|c|c|c|}
\hline \multirow{2}{*}{ عناصر } & \multicolumn{2}{|c|}{ نمونه خاك } & \multicolumn{2}{|c|}{ نمونه ا } & \multicolumn{2}{|c|}{ نمونه } & \multicolumn{2}{|c|}{ نمونه" } & \multicolumn{2}{|c|}{ نمونه r } \\
\hline & W\% & A\% & W\% & $\mathrm{A} \%$ & W\% & A\% & W\% & A\% & W\% & A\% \\
\hline $\mathrm{Na}$ & 12.65 & 15.82 & 13.51 & 19.74 & 23.17 & 23.35 & 12.15 & 15.75 & 36.49 & 49.90 \\
\hline $\mathrm{Mg}$ & 13.40 & 19.77 & 3.86 & 5.33 & 10.77 & 15.65 & 9.70 & 11.90 & 4.09 & 5.29 \\
\hline $\mathrm{Al}$ & 2.56 & 3.40 & 1.24 & 1.54 & 10.01 & 13.10 & 7.56 & 8.35 & 0.00 & 0.00 \\
\hline $\mathrm{Si}$ & 14.22 & 10.26 & 5.25 & 4.88 & 14.55 & 18.30 & 37.73 & 40.04 & 6.24 & 6.98 \\
\hline$P$ & 13.34 & 15.45 & 0.00 & 0.00 & 0.00 & 0.00 & 1.37 & 1.31 & 2.37 & 2.41 \\
\hline$S$ & 12.45 & 13.93 & 2.30 & 1.27 & 2.27 & 2.50 & 8.34 & 7.75 & 25.73 & 17.01 \\
\hline $\mathrm{Cl}$ & 14.14 & 7.30 & 63.47 & 60.12 & 15.48 & 10.85 & 4.06 & 3.42 & 8.28 & 7.30 \\
\hline $\mathrm{K}$ & 2.51 & 2.30 & 2.06 & 1.77 & 2.47 & 2.23 & 2.56 & 1.95 & 3.87 & 3.11 \\
\hline $\mathrm{Ca}$ & 8.36 & 7.48 & 2.47 & 2.07 & 2.62 & 2.31 & 2.31 & 1.72 & 2.57 & 2.01 \\
\hline $\mathrm{Cr}$ & 2.65 & 1.83 & 1.32 & 0.85 & 5.46 & 3.71 & 5.31 & 3.05 & 3.95 & 2.39 \\
\hline $\mathrm{Fe}$ & 3.83 & 2.46 & 3.27 & 1.96 & 8.66 & 5.48 & 8.90 & 4.75 & 6.41 & 3.61 \\
\hline $\mathrm{Zr}$ & 0.00 & 0.00 & 1.25 & 0.46 & 3.99 & 1.55 & 0.00 & 0.00 & 0.00 & 0.00 \\
\hline total & 100 & 100 & 100 & 100 & 100 & 100 & 100 & 100 & 100 & 100 \\
\hline
\end{tabular}

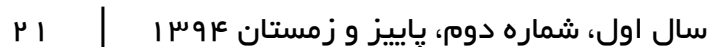


جدوله: اسيدهاى هرب موجود در نمونهها و ميزان تطابق آنها با مواد ييشنهادى

\begin{tabular}{|c|c|c|c|c|c|c|c|}
\hline \multirow{4}{*}{ موجود در نمونهها } & \multicolumn{2}{|c|}{ نمونه 1} & \multicolumn{2}{|c|}{ نمونه r } & \multicolumn{2}{|c|}{ نمونه } & نمونه F \\
\hline & نوع اسيد & درصد تطابق & نوع اسيد & تملرة & نوع اسيد & درصد تطابق & - \\
\hline & لينولئيك اسيد & $q q$ & كايريك اسيد & $\Delta \Delta$ & اولئيك اسيد & \&9 & - \\
\hline & استئاريك اسيد & ste & اولئيك اسيد & is & - & & - \\
\hline
\end{tabular}

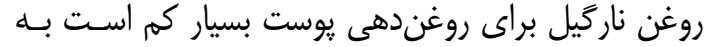

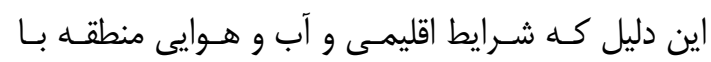
درخت ناركيل سازكارى ندارد. در نتيجه انتظار مىرود كـه

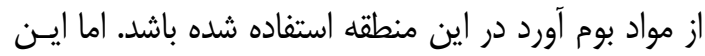

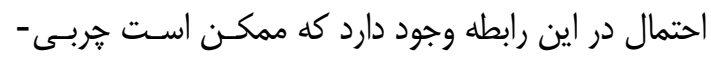

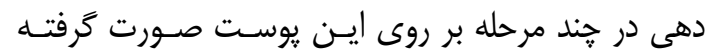

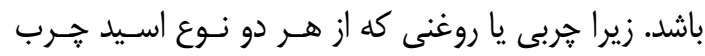

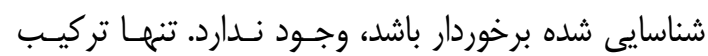

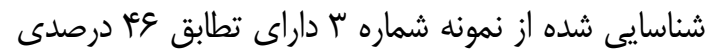
با اولئيك اسيد است كه در جـدول 9 منـابع طبيعى ايـن

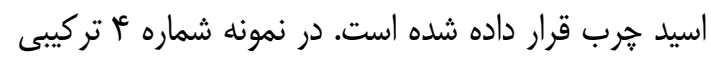

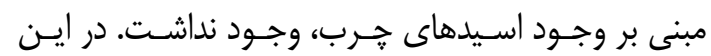

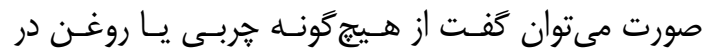

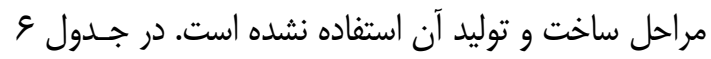
مهمترين منابع استئاريك اسيد، لينولئيك اسـيد، كايريـى اسيد و اولئيك اسيد آورده شده است.

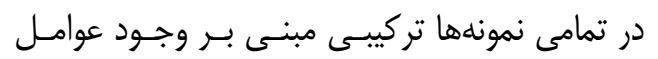

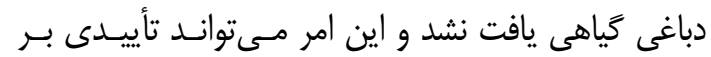

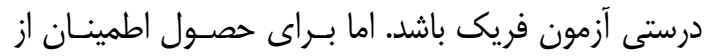

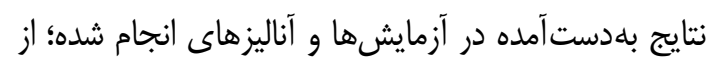

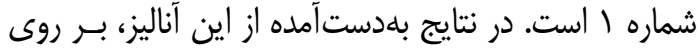

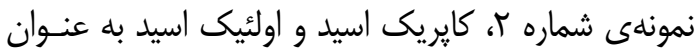

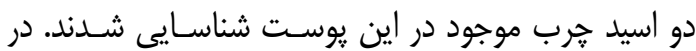

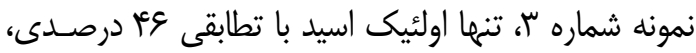

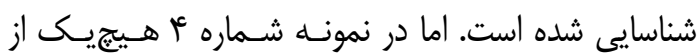
تركيبات اسيدهاى جرب حضور نداشتند و بــين معناسـت كه موادى جهت روغندهي اين نمونه استفاده نشده است

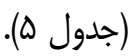
دستخاه MS، تطابق لينولئيى اسيد و استئاريك اسيد

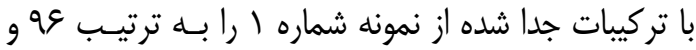

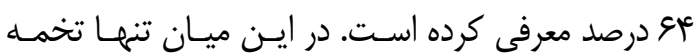
آفتابخردان است كه از مقادير مشخصى استئاريك اسـيد و

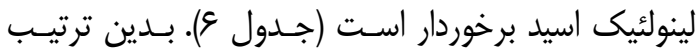

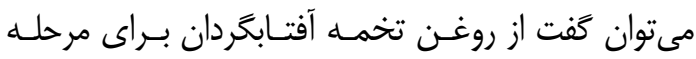
روغندهى در نمونه شماره ا استفاده شده است. در نمونــهـ

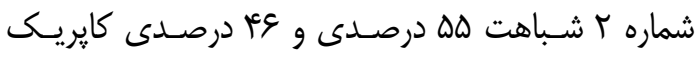

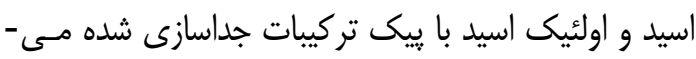
تواند سندى بر حضور اين تركيبات در يوست مـورد آنـاليز

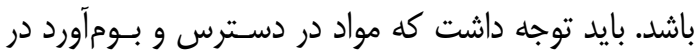

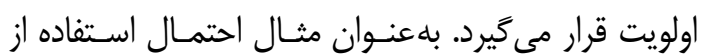

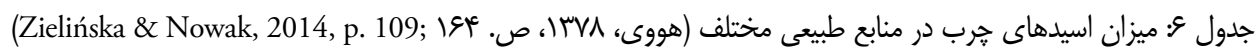

\begin{tabular}{|c|c|c|c|c|c|c|c|}
\hline \multicolumn{2}{|c|}{ كايريك اسيد } & \multicolumn{2}{|c|}{ لينولئيك اسيد } & \multicolumn{2}{|c|}{ استئريك اسيد } & \multicolumn{2}{|c|}{ اولئيك اسيد } \\
\hline منبع طبيعى & درصد & منبع طبيعى & درصد & منبع طبيعى & درصد & منبع طبيعى & درصد \\
\hline ناركيل & $r-\Lambda$ & روغن هسته انكَور & VQ & گاو و گوسفند & r. & ز زيتون & $\vee \Delta$ \\
\hline \multirow[t]{6}{*}{ خربى شير (كره) } & $r-r$ & 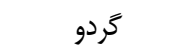 & $v^{m}$ & تخم آفتابكر دان & r. & كاو و كوسفند & ra \\
\hline & & تخمم آفتابكردان & vr & زيتون & r & تخم آفتابخردان & 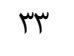 \\
\hline & & خشخاش & vr & & & ذرت & te \\
\hline & & ذرت & q. & & & 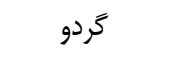 & $M$ \\
\hline & & جوانه كَندم & $\Delta \Delta$ & & & خ & 19 \\
\hline & & ينبهدانه & Dr & & & تخم كتان & 10 \\
\hline
\end{tabular}




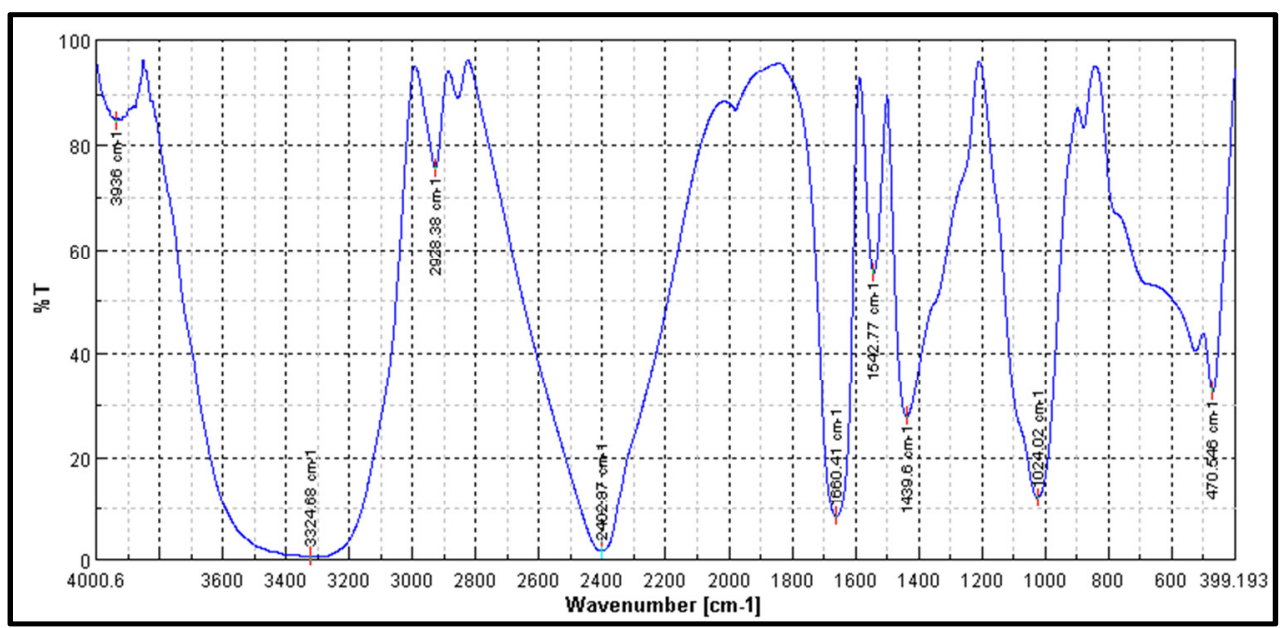

شكله: طيف FT-IR نمونه شماره

در اسيد كربوكسيليك و همجنين يك باند در ناحيه

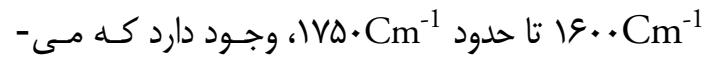

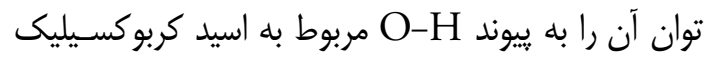
منسوب كرد. در آناليز گرفته شده از نمونه شـماره بَ نيـز دو ناحيـهـ

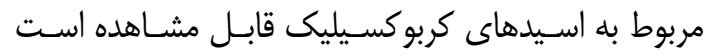

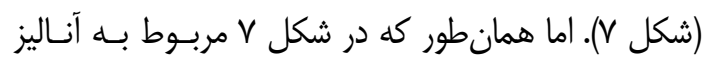

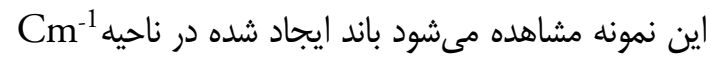
عاعب نسبت به دو نمونه قبل ضعيفتر است. بـاين حسال

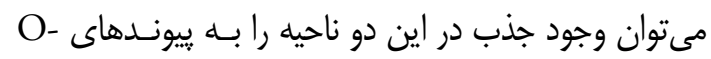
و مربوط به گروه اسيدكربوكسيليك دانست.

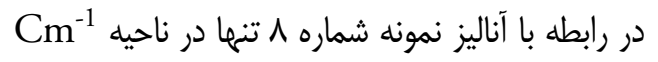

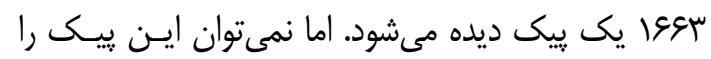

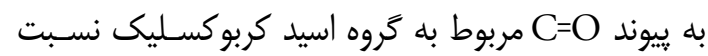

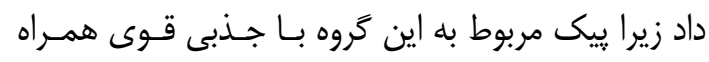

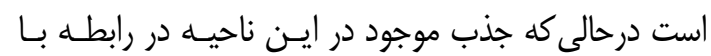
نمونه شماره عا از اين ويزگى برخوردار نيست (شكل م).

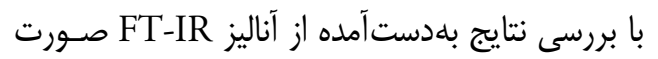

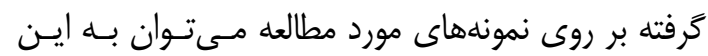

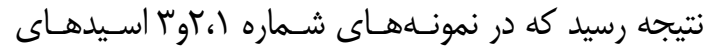

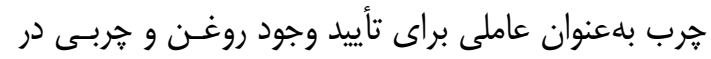
فر آيند جربى تهدهى، حضور دارند اما در آناليز نمونه شماره

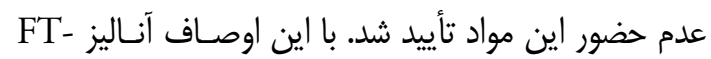

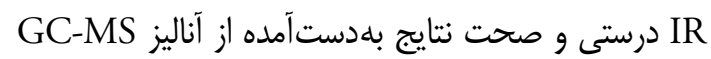
را تأييد مى كند.
آناليز FT-IR نيز استفاده شد تا در بييرامون بررسىها و مطالعات صورت گرفته، حدس و گمان كمترى باقى بماند. نواحى مهمى كه بر مبناى ساختار شيميايى تركيبـات

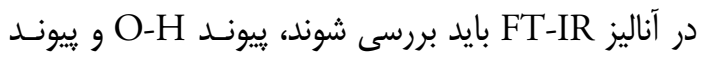

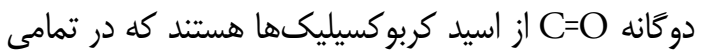

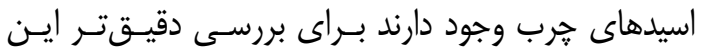

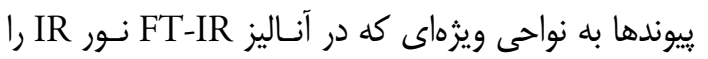
جذب مى كنند، اشاره مى يودو.

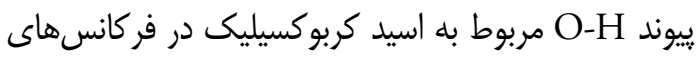

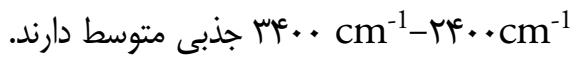
ييوند C=O مربوط به اسيد كربوكسيليك در فر كانسهاى IVTD cm $\mathrm{cm}^{-1}$ - IV · c $\mathrm{cm}^{-1}$ cm cm

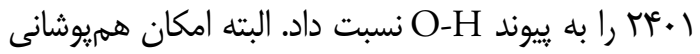
جذبهاى مربوط به ييوند C=O نتيجه با مشكل مواجه مى كند اما مىتوان علت قوى بودن جذب مرنب حاصله را وجود اين ييوند دانست. اما اين نكتـه نيـز قابـل ميل مئل

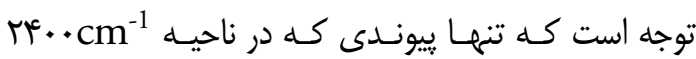

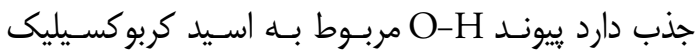

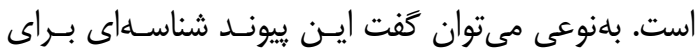

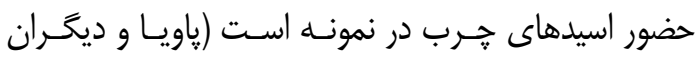

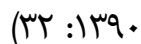
همانطور كه در شـكل \& ؤ مربـوط بـه آنـاليز نمونـهـ

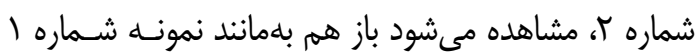
در ناحيه حدود 


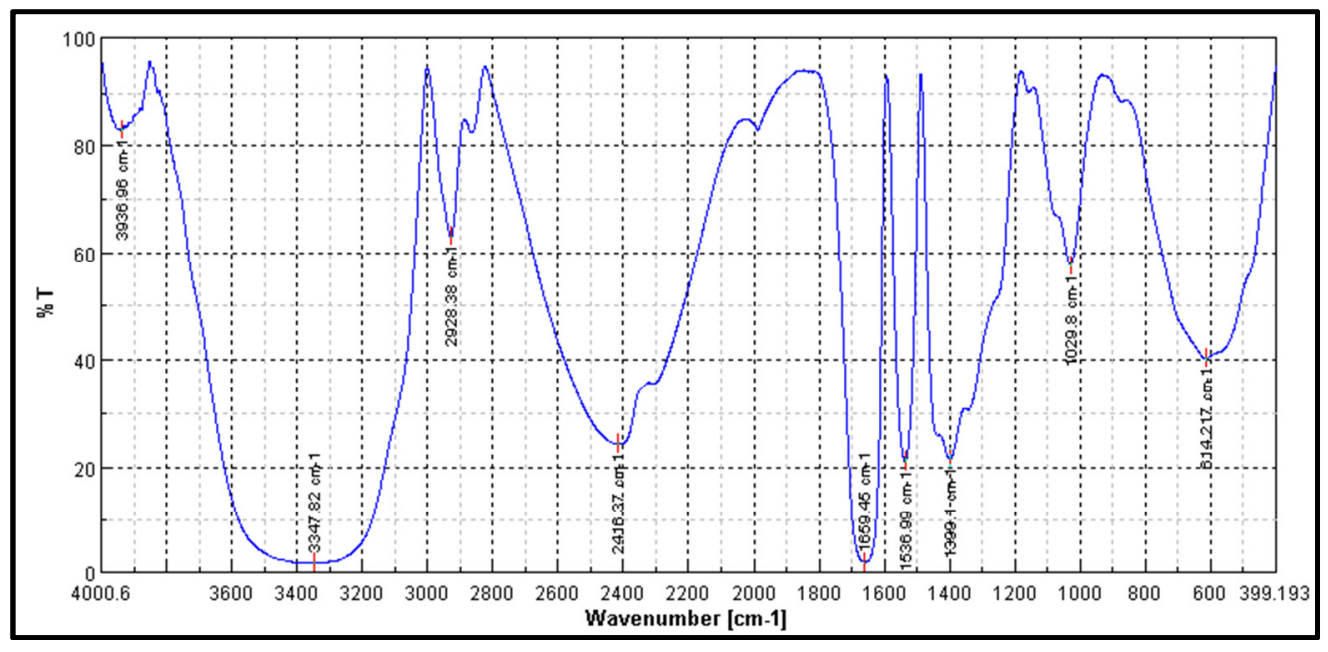

شكل צ: طيف FT-IR در نمونه شماره

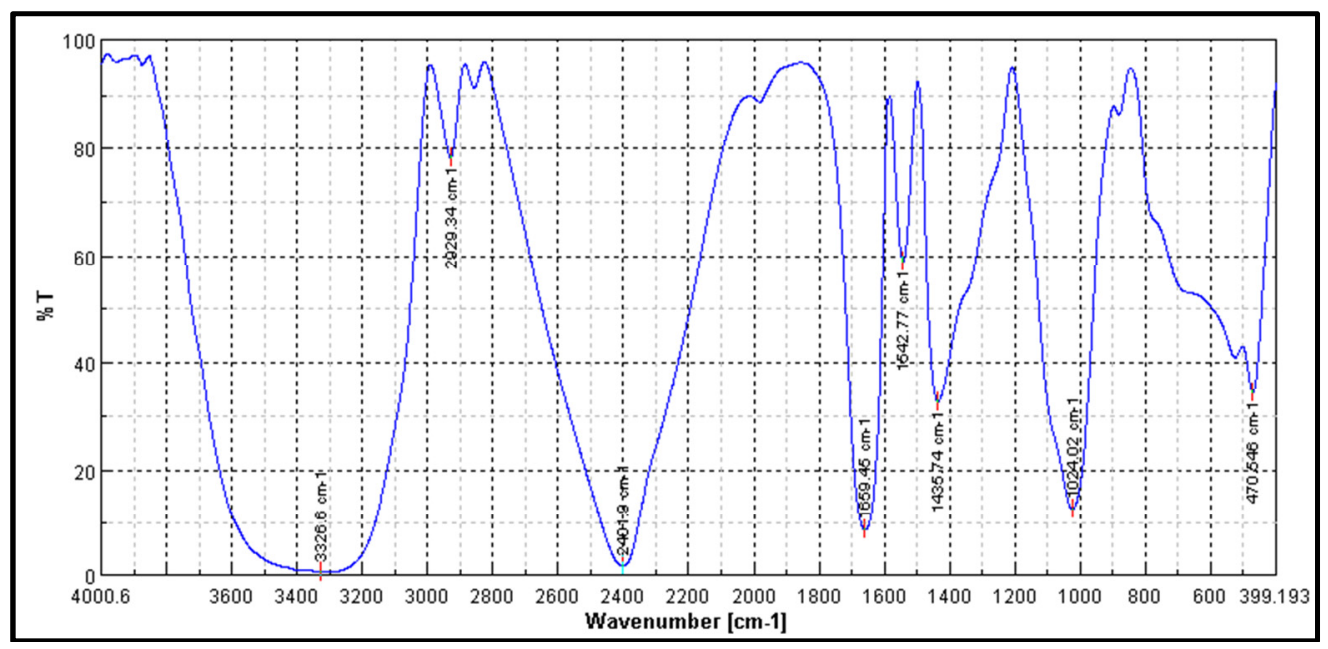

شكل V: طيف FT-IR در نمونه شماره

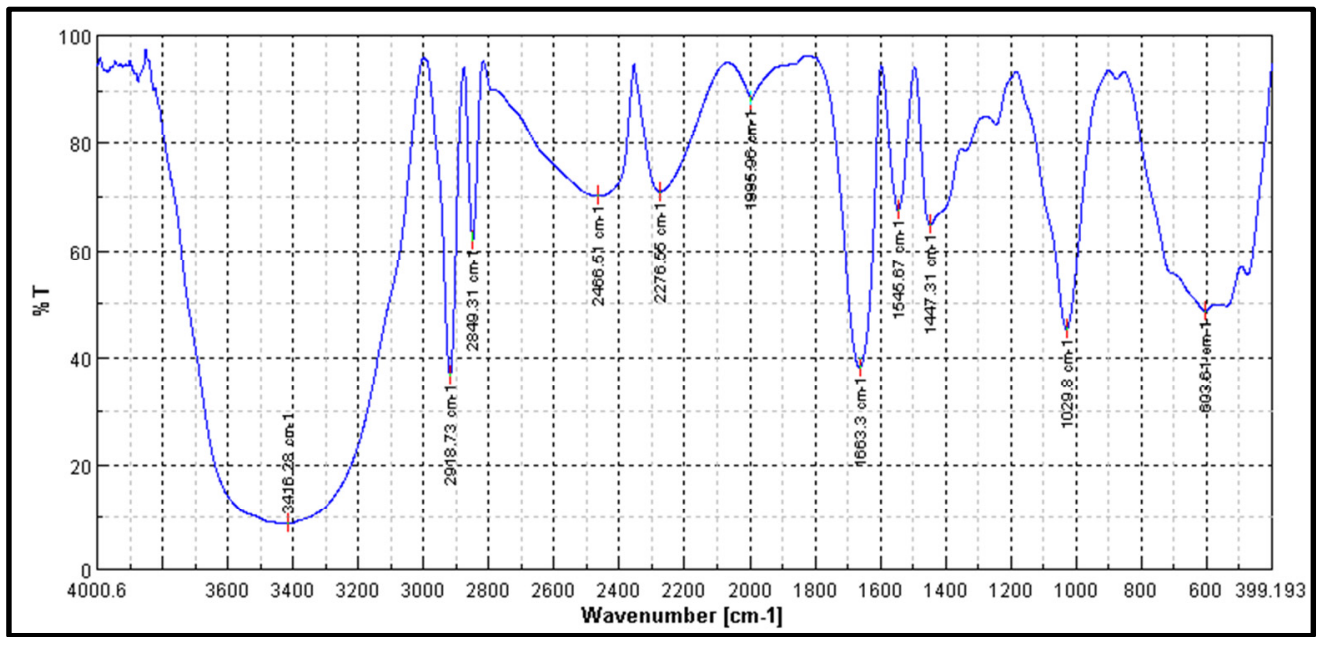

شكلم: طيف FT-IR در نمونه شماره 
زنجان و دانشخاه هنر اسلامى تبريز و دانشكاه تبريـز در

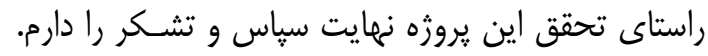

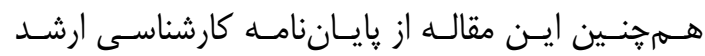

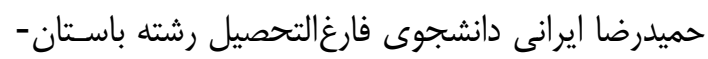

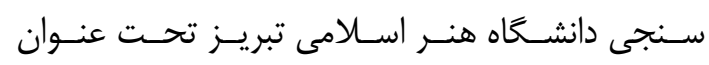

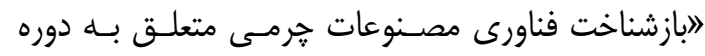

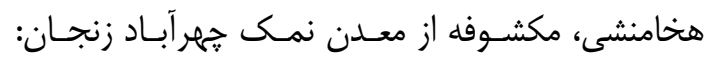
برمبناى تحليلهاى باستانسنجى" استخراج شده است.

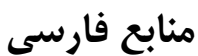

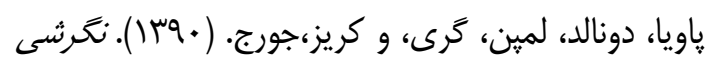

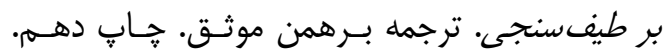
تهران: علمى و فنى. تئ.

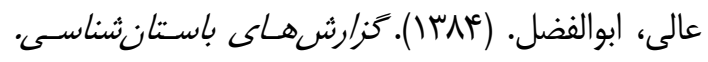
تهران: يخوهشكده باستان شناسى.

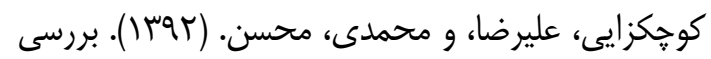

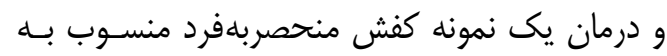

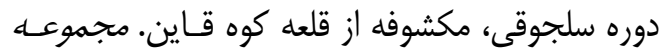

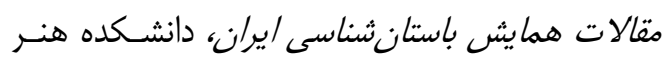

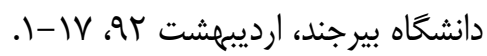

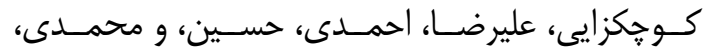

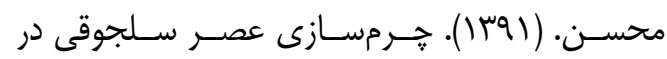

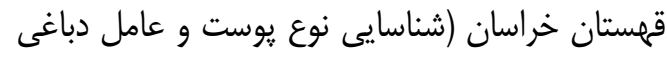

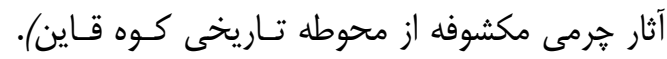

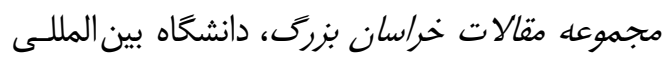

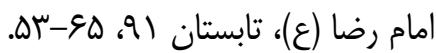

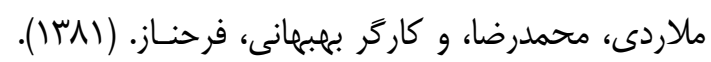
شيمى و تكنولوزى هرم: شامل مباحث ساختار بيوست

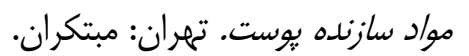

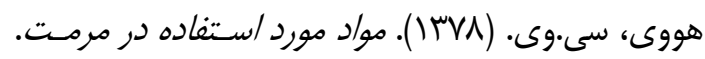
ترجمه: ابوالفضل سمنانى و فرهمند بروجنى. تهـران: علمى و فرهنگى.

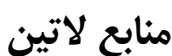

Abdel-Maksoud, G. (2011). Analytical techniques used for the evaluation of a 19th century quranic manuscript conditions. Measurement, 44(9), 16061617.

\section{1- نتيجل}

نتايج حاصل از بررسى و تحليل دادههاى بلهدست آمده از

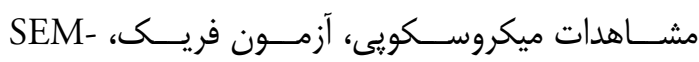

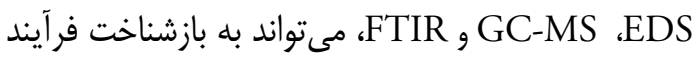
ساخت و توليد مصنوعات مورد مطالعه بسيار كمك كنـد. در اين بزوهش سعى بر آن شده كه با تركيب دستخاهها،

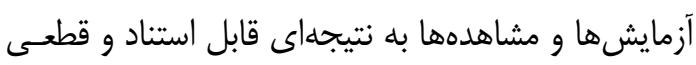

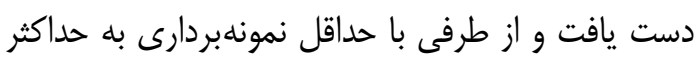

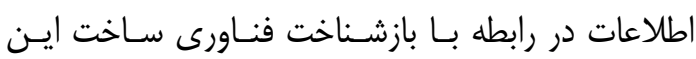

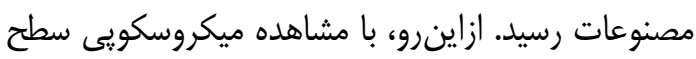
مقطع عرضى نمونهها و بررسى نسبت بين لايه كرين و و

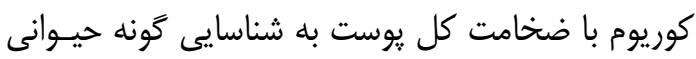

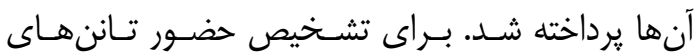

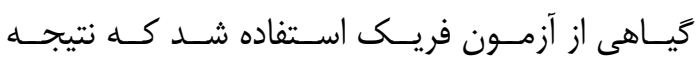

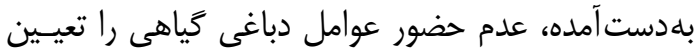

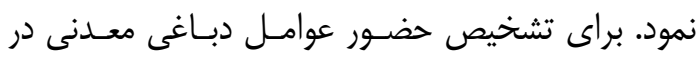

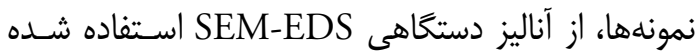

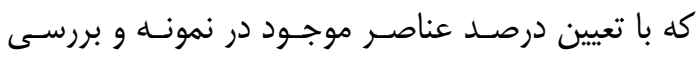

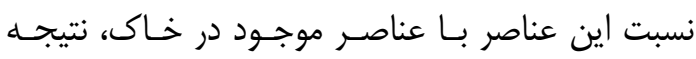

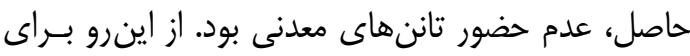

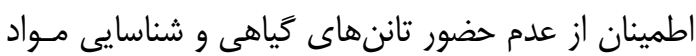

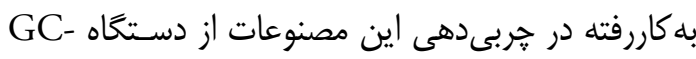

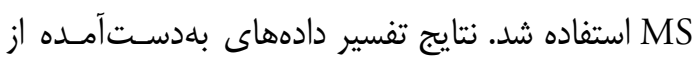

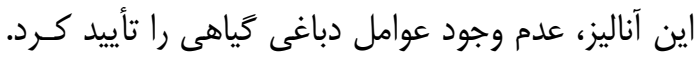

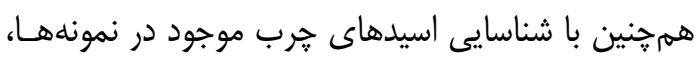

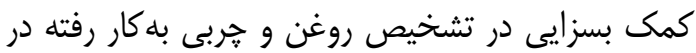
هربىدهى اين مصنوعات دارد. در ادامه براى تثبيت ائ داين

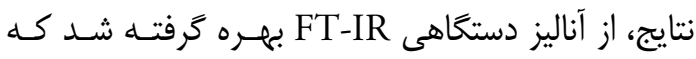

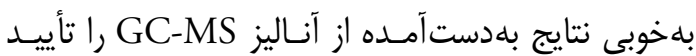

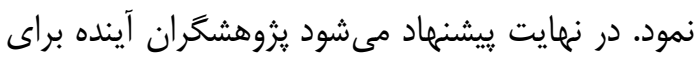

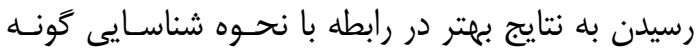

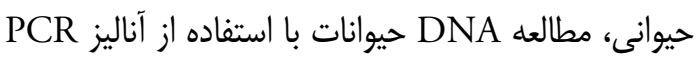

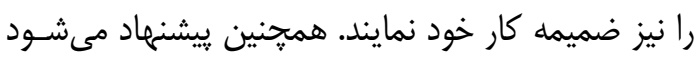

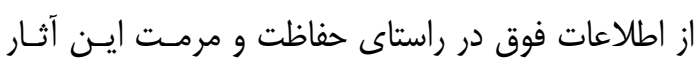
ارزشمند همر اه موميايى ها استفاده خَردد.

\section{سياسگزارى}

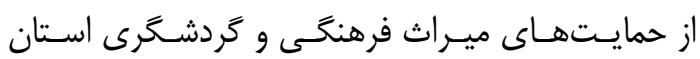


Falcão, L., \& Araújo, M. E. M. (2011). Tannins characterisation in new and historic vegetable tanned leathers fibres by spot tests. Journal of Cultural Heritage, 12(2), 149-156.

Haines, B.M. (2006).The fibre structure of leather", In: Conservation of Leather and RelatedMaterials, M. Kite \& R.Thomson (Eds.), London: ButterworthHeinemann, Pages 11-21.Haines, B.M.1981. The fibre structure of leather (1ed.), Northampton: The LeatherConservation Centre.

Hurcombe, M.Linda. (2007). The science and archaeology of materials. London: routledge.

Pollard, A. M., Brothwell, D. R., Aali, A., Buckley, S., Fazeli, H., Dehkordi, M. H., ... \& Wilson, A. S. (2008). Below the salt: a preliminary study of the dating and biology of five salt-preserved bodies from Zanjan Province, Iran. Iran, 135-150.

Zielińska, Aleksandra , Nowak, Izabela. (2014). Fatty acids in vegetable oils and their importancein cosmetic industry. science technique. Chemik 2014, 68, 2, 103-110. 